\title{
PRZYGOTOWANIE LEGENDY DO PRACY Z DZIECKIEM POLONIJNYM
}

\begin{abstract}
Słowa kluczowe: legenda, dziecko polonijne, Polonia, język polski jako odziedziczony, adaptacja tekstu
\end{abstract}

Streszczenie. Artykuł podejmuje problem obecności legend w procesie nauczania dzieci polonijnych w tzw. szkołach sobotnich. Edukacja polonistyczna dzieci mieszkających poza Polską nie jest łatwa. Zwykle uczęszczają one na lekcje w szkołach sobotnich, które przez kilka godzin w tygodniu mają za zadanie podtrzymać „,polskość” dziecka poprzez rozwój biegłości językowej i zapoznanie z polską kulturą. Nauczyciele szkół sobotnich często nie mają odpowiedniego przygotowania i wsparcia, a spoczywa na nich bardzo duża odpowiedzialność. Autor zwrócił uwagę na korzyści płynące z wykorzystania polskich legend, które stanowią (jako jedne z nielicznych tekstów literackich) wspólną przestrzeń kulturową dziecka polonijnego, rodzica, rodziny i kolegów w Polsce. Zaprezentowano zasady adaptacji tekstów legend polskich do poziomu biegłości językowej dziecka oraz przedstawiono najczęstsze błędy popełniane przy przygotowaniu tekstów adaptowanych.

\section{UWAGI WSTEPNE}

Wydaje się, że ciągle na marginesie (przynajmniej w Polsce) pozostaje glottodydaktyka polonistyczna zorientowana na język, jakim posługuje się polonijna społeczność. Owszem, popularne i niezwykle ważne są opracowania bilingwizmu dzieci polonijnych: czy to w Australii (Lipińska 2003; Dębski 2009), czy w USA (Jędryka 2012; Seretny, Lipińska 2012), czy w krajach niemieckojęzycznych (Cieszyńska 2006), jednak za mało uwagi poświęca się nauczaniu dzieci polonijnych. W. Hajduk-Gawron zauważa, że ,dotychczasowe prace glottodydaktyków polonistycznych dotyczyły zwykle edukacji języka polskiego jako obcego wśród dorosłych lub wśród dzieci i młodzieży z kręgów polonijnych albo Polaków na Wschodzie" (Hajduk-Gawron 2019, s. 294). Mimo badań A. Seretny i E. Lipiń-

"mateusz.gaze@uni.lodz.pl, Uniwersytet Łódzki, Wydział Filologiczny, Instytut Filologii Polskiej i Logopedii, Zakład Lingwistyki Stosowanej i Kulturowej, ul. Pomorska 171/173, 90-236 Łódź. 
skiej (2013) czy G. Czetwertyńskiej (2015) nauczanie języka polskiego dzieci polonijnych w Europie Zachodniej to dalej terra incognita.

Przede wszystkim związane jest to z bardzo dynamiczną sytuacją języka polskiego poza granicami kraju, zwłaszcza w Europie Zachodniej. Od początków XXI wieku zauważalna jest duża fala emigracji Polaków do: Wielkiej Brytanii, Irlandii, Szwecji, Holandii, Niemiec, Norwegii itp. Poziom językowy dzieci Polaków w tych krajach jest niestabilny (każdy rok przynosi raczej jego pogorszenie), a i trudno jest często ustalić status polszczyzny dzieci. Czy język polski dla dzieci polonijnych jest językiem ojczystym (,zagranicznym” językiem ojczystym ${ }^{1}$ ), językiem funkcjonalnie pierwszym, językiem (funkcjonalnie) drugim, językiem odziedziczonym czy może językiem obcym² ${ }^{2}$ ? Bardzo ważny jest również fakt, czy język polski dla tych dzieci jest językiem domowym, czy też językiem edukacyjnym (w tzw. szkołach sobotnich).

Celem niniejszego artykułu jest zaprezentowanie legendy polskiej jako tekstu, który powinien być wykorzystany na lekcjach w tzw. szkołach sobotnich kształcących dzieci polonijne (dzieci polskiego pochodzenia). Najpierw omówiono specyfikę nauczania w szkołach sobotnich, co pozwoliło nakreślić problemy tychże jednostek. Następnie przedstawiono korzyści, jakie płyną z wykorzystania legend na lekcji z dzieckiem polonijnym oraz trudności, jakie może napotkać nauczyciel, chcąc wykorzystać ten typ tekstu. Na koniec przedstawiono zasady adaptacji tekstów adresowanych do dzieci w Polsce, które pozwolą dostosować tekst legendy do specyfiki lekcji w szkole sobotniej i umiejętności językowych dziecka polonijnego.

\section{SZKOLY SOBOTNIE}

Szkoły sobotnie to instytucje funkcjonujące za granicą na zasadach prawa danego kraju. Często są to instytucje, które działają raz w tygodniu (w sobotę lub w niedzielę), a których celem jest kształcenie dzieci Polaków, na co dzień korzystających z systemu edukacji kraju zamieszkania, a dodatkowo raz w tygodniu posyłanych na lekcje języka polskiego, polskiej historii i geografii Polski.

Zajęcia w szkołach sobotnich stanowią często zbyt duże obciążenie dla polskich dzieci. Odbywają się w czasie wolnym dzieci - kosztem zajęć własnych czy rozwijania zainteresowań ${ }^{3}$. Skutkuje to tym, że zwykle w wyższych klasach szkół sobotnich jest coraz mniej dzieci. Nauczyciele często sygnalizują, że dzieci posyłane są do szkół sobotnich do końca III klasy, ponieważ to wtedy dziecko przystępuje do sakramentu Pierwszej Komunii Świętej, do którego przygotowaniem

\footnotetext{
${ }^{1}$ Tego roboczego terminu używają E. Lipińska i A. Seretny (2019).

${ }^{2}$ Więcej na ten temat problemów z nazewnictwem w pracy E. Lipińskiej i A. Seretny (2019).

${ }^{3}$ Nauczyciele szkół polonijnych i rodzice często sygnalizują, że dzieci mają pretensje, że muszą w weekend dodatkowo się uczyć, zamiast np. pójść na trening piłki nożnej czy na zajęcia z fotografii.
} 
zajmuje się również szkoła. W następnych latach i rodzice (muszą przecież opłacić czesne oraz poświęcić czas na zawiezienie i odebranie dziecka), i dzieci tracą motywację do kontynuowania nauki. Autorzy Poradnika dla animatorów szkolnictwa polonijnego, nauczycieli i rodziców (Czetwertyńska i in.), jednego z nielicznych opracowań qusi-metodycznych (nie naukowych!) dla nauczycieli dzieci polonijnych, sygnalizują dwa ważne problemy związane z funkcjonowaniem szkół sobotnich. Na nauczycielu spoczywa duża odpowiedzialność: musi zachęcić dziecko do tak dużego dla niego wysiłku, by chciało poznać język i kulturę kraju rodzica/ rodziców i utrzymało jak najdłużej tę motywację, ponadto musi utrzymać dobre stosunki z rodzicem ucznia, by ten chciał jak najdłużej posyłać dziecko do szkoły i przede wszystkim współpracował z nauczycielem w edukacji polonistycznej ${ }^{4}$. Należy mieć świadomość, że ,nauczyciel języka polskiego za granicą staje zwykle przed koniecznością stałego zatrudnienia w innym miejscu pracy niż szkoła. Wynika to z małej liczby godzin nauczania języka polskiego w szkołach sobotnich lub języka ojczystego w szkołach miejscowego systemu oświaty" (Czetwertyńska i in., s. 28). Dlatego też w szkołach sobotnich nie uczą tylko poloniści czy osoby z przygotowaniem pedagogicznym ${ }^{5}$, często są to rodzice, wolontariusze czy po prostu osoby, dla których podtrzymanie polskości i rozwój językowy dzieci polonijnych jest ważny. Do podjęcia pracy nauczyciela polonijnego nie zachęca również fakt, że „korzysta się najczęściej z własnych, samodzielnie opracowanych (...) programów nauczania, dostosowanych do możliwości organizacyjnych szkoły i poziomu znajomości języka polskiego uczniów" (Czetwertyńska i in., s. 12). Co prawda powstaje coraz więcej podręczników adresowanych do dzieci polonijnych ${ }^{6}$, ale nie wyczerpują one potrzeb tak zróżnicowanego środowiska polonijnego.

\section{LEGENDA JAKO TEKST GLOTTODYDAKTYCZNY}

Legenda to opowieść związana z jakimiś historycznymi (lub uważanymi za historyczne) postaciami, wydarzeniami albo miejscami (Głowiński i in. 2008, s. 391). Utrwalona jest w tradycji i zazwyczaj przekazywana w formie ustnej na

${ }^{4}$ Dziecko nie może mieć kontaktu z językiem polskim tylko raz w tygodniu przez 4-5 godzin. Rodzic w tygodniu powinien rozmawiać $\mathrm{z}$ dzieckiem po polsku i próbować zachęcać je zarówno do rozwoju językowego, jak i zgłębiania szeroko pojętej kultury polskiej.

${ }^{5}$ Trudno też oczekiwać, by we wszystkich miastach, w których działają szkoły sobotnie (baza szkół http://polska-szkola.pl/db/web/database/baza-danych-szkol [10.06.2020] odnotowuje ok. 1000 szkół na całym świecie) znaleźli chętni poloniści z przygotowaniem pedagogicznym (utopijne byłoby marzenie o przygotowaniu glottodydaktycznym).

${ }^{6}$ Także w Polsce powstawały książki adresowane do dzieci i młodzieży (m.in. autorstwa M. Szelc-Mays (2014), A. Rabiej (2009, 2010), A. Achtelik i B. Niesporek-Szamburskiej (2016)). 
długo przed zapisaniem. Legendy składają się często z nieprawdopodobnych albo nierealnych motywów. Od mitów odróżnia jest fakt, że oparte są na wydarzeniach historycznych (lub uważanych za historyczne) oraz że skupiają się na ludziach (nie na bogach) (Baldick 2001, s. 138). Dlaczego zatem legendę warto wykorzystać w pracy z dziećmi polonijnymi w szkołach sobotnich (i nie tylko w nich)? By odpowiedzieć na to pytanie, warto jeszcze raz powtórzyć, że celem edukacji polonistycznej w polskiej szkole sobotniej nie jest tylko opanowanie języka, lecz także poznanie kultury kraju rodzica i rodziny rodzica. Dzieci polonijne (zwłaszcza te związane z najnowszą falą emigracyjną do państw Europy Zachodniej) często odwiedzają Polskę, czy to przy okazji świąt, czy wakacji. Legendy (nazwijmy je kanonicznymi ${ }^{7}$ ) stanowią przestrzeń kulturową wspólną dla dziecka polonijnego, jego rodziców, rodziny w Polsce, polskich kolegów. Tak naprawdę to legendy (jako jedne z nielicznych tekstów literackich ${ }^{8}$ ) są znane zarówno dziecku polonijnemu, jak i pozostałym Polakom. Dziecko wychowane w środowisku polonijnym często nie zna dłuższych tekstów polskich powieści czy opowiadań, które omawiane są w polskim systemie edukacji.

Legendy polskie są jednym $\mathrm{z}$ elementów budujących lingwakulturę polską, czyli ,językowy obraz wartości, symboli, sensów charakterystycznych dla danego obszaru kulturowego" (Zarzycka 2004, s. 438), który dla rodzimych użytkowników języka jest czymś naturalnym ${ }^{9}$, zaś dzieciom polonijnym może być nieznany, a w kontakcie z Polakami (niekoniecznie tylko tymi żyjącymi w Polsce) może utrudniać komunikację i zrozumienie. Badaczka, postulując odkrywanie zasobów lingwakulturowych w procesie dydaktycznym, jako pierwszy sposób podaje właśnie: „wskazywanie połączeń między specyficznie polskimi nazwami a ich znaczeniem w kulturze polskiej i języku polskim, a także nacisk na przyswojenie przez uczących się kanonu znaczących nazw własnych: nazwisk twórców, imion bohaterów literackich i filmowych, tytułów dzieł i egzotyzmów polskich" (Zarzycka 2008, s. 151). W legendach zawarte są przecież ważne kulturemy, czyli znaczące elementy kultury, bogate w znaczenia, pełniące funkcję jej interpretanta (Zarzycka 2019, s. 426), które w tym przypadku egzemplifikowane są przez nazwy własne postaci czy miejsc, jak np. Smok Wawelski, Popiel, Mysia Wieża, Wars i Sawa, Piast). Co więcej, dziecko polonijne wykorzysta poznaną treść legendy i pojawiające się w nich kulturemy - podróżując po Polsce, spotka się z postaciami i miejscami z legend. Dzięki temu łatwiej mu będzie zrozumieć otaczające go elementy rzeczywistości

\footnotetext{
${ }^{7}$ Mam na myśli tutaj takie legendy jak: o Piaście, o Popielu, o Wandzie, co nie chciała Niemca, o Smoku Wawelskim, o Warsie i Sawie etc.

${ }^{8}$ Do grupy tej można zaliczyć inne krótkie teksty, które polskie dziecko poznaje w szkole, jak np. Katechizm polskiego dziecka W. Bełzy czy Mazurek Dąbrowskiego.

${ }^{9}$ G. Zarzycka (2004, s. 438), opisując lingwakulturę, posługuje się metaforą atmosfery, niewidocznej, ale koniecznej do życia (językowego).
} 
(np. pomnik Smoka Wawelskiego w Krakowie czy Mysią Wieżę w Kruszwicy). Dziecko będzie je odbierać jako znane, swoje, poczuje się częścią tej rzeczywistości, częścią kraju.

Legenda jest tekstem lubianym przez dzieci polonijne, ponieważ jest zazwyczaj krótka (a na pewno krótsza od opowiadań czy powieści). Jest to tekst atrakcyjny dla dziecka, ponieważ zawiera elementy fantastyczne, często pojawiają się w nim momenty grozy i/lub cudowności czy baśniowości. Legendę, podobnie jak baśń, cechują „konsekwentnie ułożone losy bohaterów, wyraziste, często schematyczne ich portrety i klarowna fabuła nawiązująca do przyczynowo-skutkowego układu zdarzeń" (Michułka 2008, s. 199), co ułatwia jej odbiór. Ponadto wykorzystanie tekstu literackiego stanowi cenne źródło wiedzy o języku i kulturze oraz ma szanse urozmaicić zajęcia i wpłynąć motywująco na uczącego się (Tsai 2010, s. 403). T. Czerkies definiuje nawet w perspektywie glottodydaktycznej kompetencję literacką i określa jej miejsce w relacji z innymi (tradycyjnie wyróżnianymi) kompetencjami: ,[jest ona] zakotwiczona w wielu kompetencjach jednocześnie: przez uruchamianie języka - w kompetencji językowej; przez reakcję interakcyjną na tekst literacki - w kompetencjach komunikacyjnych: dyskursywnej i funkcjonalnej; zaś przez zdolność porozumiewania się i oswajania nowej kultury - w kompetencji interkulturowej” (Czerkies 2012, s. 104). Wyniki sondy przeprowadzonej wśród nauczycieli w szkołach polonijnych (zapytano 30 nauczycieli) pokazały, że wszyscy respondenci uważają, że legenda jest tekstem, który powinien być omawiany na lekcji z dzieckiem polonijnym. 22 osoby odpowiedziały, że chętnie wykorzystują ten rodzaj tekstu. 8 osób, które wskazało, że niechętnie sięga po legendę, w uzasadnieniu podało, że trudno pracuje im się $\mathrm{z}$ takim tekstem, ponieważ: jest zbyt długi (5 osób), zawiera zbyt trudne słowa (5 osób), zawiera zbyt trudne konstrukcje składniowe (4 osoby), zawiera zbyt długie wypowiedzenia ( 3 osoby). 19 osób odpowiedziało ponadto, że legendy polskie są obecne nie tylko na zajęciach z języka polskiego, lecz także na lekcjach historii i wiedzy o Polsce.

\section{ADAPTACJA TEKSTÓW LEGEND}

Wykorzystanie tekstów legend z wydawnictw przeznaczonych dla dzieci w Polsce często jest niemożliwe w szkole sobotniej, ponieważ są to zwykle teksty zbyt długie i zbyt trudne (zarówno pod względem struktur gramatycznych, jak i zasobu leksykalnego $)^{10}$. Nauczyciel szkoły polonijnej powinien zatem stworzyć

${ }^{10}$ Dla przykładu w Legendach polskich W. Chotomskiej (2001) legendy: o Popielu, o Piaście, o Smoku Wawelski liczą po 5 stron. 
tekst adaptowany ${ }^{11}$ legendy na poziomie A $2^{12}$. Pozwoli to pozostawić z zagadnień gramatycznych:

- wszystkie formy przypadków;

- czasy: przeszły, teraźniejszy, przyszły w aspekcie dokonanym i niedokonanym;

- tryby: oznajmujący, przypuszczający, rozkazujący;

- stopniowanie przymiotników i przysłówków: proste (regularne i supletywne) i opisowe;

- zdania złożone współrzędnie ze spójnikami: $i, a$, a także, lub, albo, czy, więc, ale;

- zdania złożone podrzędnie ze spójnikami: że, bo, dlatego że, kiedy, gdy, $\dot{z} e b y^{13}$.

Należy usunąć z tekstu:

- konstrukcje strony biernej;

- imiesłowy i imiesłowowe równoważniki zdania;

- formy nieosobowe;

- wypowiedzenia wielokrotnie złożone;

- zbyt trudne frazeologizmy;

- zdania złożone podrzędnie ze spójnikami: jeżeli ..., to ..., gdyby .., to ..., im ..., tym ....;

- trudne w odmianie czasowniki (np. plesśc, siasść, piec, wieźć).

W latach 2015-2020 na zajęcia z kultury w nauczaniu języka polskiego prowadzonych zarówno w ramach specjalizacji polonistycznej czy neofilologicznej na Uniwersytecie Łódzkim, jak i na studiach podyplomowych na Polskim Uni-

${ }^{11} \mathrm{~W}$ glottodydaktyce polonistycznej od wielu lat wyróżnia się trzy typy tekstów: prymarne, adaptowane i sekundarne. Tekstami prymarnymi nazywa się teksty oryginalne, których forma i treść nie były poddawane przystosowaniom do poziomu uczących się czy do innych celów dydaktycznych. Teksty adaptowane (adaptaty - Gaze, Góralczyk-Mowczan 2015) powstają na bazie tekstów oryginalnych, ale upraszczane są do względem gramatyczno-leksykalnym. Teksty sekundarne, nazywane inaczej preparowanymi, zostały sztucznie stworzone przez lektora na potrzebę wprowadzenia lub utrwalenia danego zagadnienia językowego (Kozłowski 1991). A. Dunin-Dudkowska i A. Trębska-Kerntopf dodają, że teksty adaptowane są domeną poziomu średniozaawansowanego, ale obecnie można już je wykorzystywać wcześniej (Dunin-Dudkowska, Trębska-Kerntopf 1998, s. 37). Adaptacja tekstu zakłada bowiem jego opracowanie i przystosowanie do innego użytku niż był pierwotnie przeznaczony. Wydaje się, że ,autorzy najnowszych podręczników, nawet tych przeznaczonych na poziom A1 i A2, coraz częściej starają się zastępować teksty sztucznie wygenerowane tekstami w mniejszym lub większym stopniu poddanymi adaptacji” (Gaze, Góralczyk-Mowczan 2015, s. 239).

${ }^{12}$ Umiejętności, jakie przypisuje się uczącym języka polskiego jako obcego, którzy opanowali polszczyznę na poziomie A2, odpowiadają poziomowi językowemu dziecka polonijnego w III-IV klasie szkoły podstawowej.

${ }^{13} \mathrm{Na}$ podstawie Standardów wymagań odnoszących się do poszczególnych poziomów biegłości językowej w zakresie znajomości języka polskiego jako obcego, zał. 1 do rozporządzenia Ministra Nauki i Szkolnictwa Wyższego z dnia 26 lutego 2016 r. (poz. 405). 
wersytecie na Obczyźnie w Londynie studenci mieli za zadanie zaadaptować tekst polskiej legendy ${ }^{14}$. Zgromadzono łącznie 98 prac studenckich, w których powtarzały się następujące błędy:

- brak selekcji informacji i skupienie się na elementach zbędnych (np. zbyt obszernych opisach wyglądu postaci lub zbyt długich opisach okoliczności towarzyszących) ${ }^{15}$;

- niedostosowanie języka i słownictwa do założonego poziomu (np. obmyślić plan zam. zaplanować, ujrzeć zam. zobaczyć, zapragnąć zam. chcieć, urodziwy zam. tadny);

- używanie potocyzmów i frazeologizmów (np. przejrzat na oczy, Popiel byt pijakiem);

- stosowanie zbyt trudnych konstrukcji składniowych (zwłaszcza imiesłowowych równoważników zdania, strony biernej i form nieosobowych);

- stosowanie zbyt długich wypowiedzeń (dla naturalnego użytkownika języka wypowiedzenie czterokrotnie złożone nie jest trudne do zrozumienia, jednak dla dziecka, które posługuję się językiem polskim kilka godzin $\mathrm{w}$ sobotę i w kontakcie z jednym $\mathrm{z}$ rodziców, już wypowiedzenia z 3 orzeczeniami stanowią problem).

Dużym problemem w wykorzystaniu legend na lekcji języka polskiego jako obcego/drugiego/odziedziczonego jest obecność słownictwa, które związane jest $\mathrm{z}$ realiami świata przedstawionego $\mathrm{w}$ tekście, ale jest ono spoza poziomu językowego dziecka. Można tutaj wskazać następujące pola leksykalne:

- rośliny i zwierzęta: owca, dąb, świerk, orzet, zboże;

- nazwy związane z ukształtowaniem terenu: wzgórze, bagno, taka, polana, puszcza, potok;

- budowle i nazwy miejsc: zamek, pałac, komnata, karczma, chata, kopalnia;

- nazwy określające miejscowości: osada, wieś, wioska, gród;

- nazwy zawodów i pełnionych funkcji: ksiaże, władca, królewna, szewczyk, bartnik, flisak, soltys;

- nazwy czynności: handlowanie, towienie ryb, splawianie drewna, zarzucanie sieci;

- nazwy militarne: tarcza, zbroja, miecz, strzała, bitwa, walka;

- nazwy związane z realiami życia: wóz, postrzyżyny, studnia, sieć;

- nazwy istot fantastycznych/nadprzyrodzonych: czarownica, bazyliszek, smok, bies;

- nazwy magicznych zjawisk: klatwa, zaklęcie, czary, cyrograf.

${ }^{14}$ Wykorzystywano do tego celu trzy znane legendy: o Lechu, Czechu i Rusie, o Smoku Wawelskim i o Piaście.

${ }^{15}$ By nie popełniać tego błędu, dobrze jest po przeczytaniu tekstu oryginalnego stworzyć plan wydarzeń i wynotować informacje, które są fabularnie istotne. 
Oczywiście niemożliwe jest uproszczenie czy pominięcie wszystkich leksemów spoza poziomu. Nauczyciel musi dokonać selekcji i pominąć wyrazy, które w danej legendzie nie są istotne, część zastąpić synonimami (np. sekretny zam. tajemniczy, używać zam. korzystać, ubranie zam. strój) lub część sparafrazować (np. stary las zam. puszcza, powiedzieć, żeby ktoś coś zrobił zam. kazać). W przygotowanym adaptacie można zostawić kilka/kilkanaście trudnych słów, a dobrą praktyką wydaje się stworzenie do nich słowniczka pod tekstem legendy.

A. Strzelecka zauważa, że praca z tekstem autentycznym lub po adaptacji powinna uwzględniać trzy fazy procesu glottodydaktyczncgo: prezentację, objaśnienie i utrwalenie (Strzelecka 2008, s. 234). Nie można ograniczać pracy z legendą tylko do prezentacji tekstu poprzez przeczytanie go przez nauczyciela lub przez ucznia. Po prezentacji tekstu nauczyciel powinien przejść do ustnej i/lub pisemnej pracy z tekstem, mającej na celu objaśnianie i utrwalanie poznanego materiału. Dobrze jest zatem stworzyć szereg ćwiczeń do tekstu legendy (dzięki temu poza celem kulturowym: poznaniem treści legendy, elementu kultury polskiej, zrealizujemy cele językowe $)^{16}$.

\section{PODSUMOWANIE}

Reasumując, legenda jest ważnym tekstem w pracy z dzieckiem polonijnym. Stanowi wspólną przestrzeń kulturową dla dziecka, jego rodzica/rodziców oraz rodziny i kolegów w Polsce. Sonda przeprowadzona wśród nauczycieli szkół polonijnych pokazuje, że wszyscy respondenci uważają, że legenda to tekst, który musi być obecny w edukacji dziecka polonijnego. Część z nich jednak niechętnie wykorzystuje teksty legend adresowane do dzieci w Polsce. Legenda ma jednak tę przewagę nad innymi tekstami literackimi, że można ją adaptować do poziomu językowego dzieci mieszkających poza Polską. Co prawda można wskazać wiele obostrzeń dotyczących adaptacji legendy na potrzeby dziecka polonijnego, zarówno w sferze leksykalnej, gramatycznej, jak i stylistycznej, jednak na ogół nie istnieje jeden tekst kanoniczny legendy. Jest wiele wersji legend, dzięki temu nauczyciel może zmieniać pierwotny tekst tak, by odpowiadał on poziomowi dzieci polonijnych i potrzebom lekcji języka polskiego (i nie tylko). Adaptacja często jest konieczna, ponieważ wykorzystanie legend ze zbiorów przeznaczonych dla dzieci w Polsce może zniechęcić dzieci polonijne. Teksty te są często kilkustronico-

${ }^{16}$ Przykłady ćwiczeń (zarówno tych tradycyjnych, np. ćwiczenia typu prawda/fałsz, wybór trzech odpowiedzi, jak i niekonwencjonalnych, np. napisanie esemesa do braci Lecha) można znaleźć w zbiorze Legendy polskie na A2 przygotowanym przez studentów V edycji studiów podyplomowych „Nauczanie języka i kultury polskiej poza Polską” Polskiego Uniwersytetu na Obczyźnie w Londynie pod redakcją M. Gazego (2019). 
we, zawierają zbyt trudne konstrukcje gramatyczne i słownictwo spoza poziomu. Warto adaptować teksty legend, pamiętając o wskazanych w części „Adaptacja tekstów legend" zasadach i mając na uwadze fakt, że legendy w szkole sobotniej pojawiają się, by dziecko poznało ważny element (lingwa)kultury, a dzięki adaptowaniu możliwe jest dostosowanie tekstu do potrzeb lekcji.

\section{BIBLIOGRAFIA}

Achtelik A., Niesporek-Szamburska B., 2016, Bawimy się w polski 1. Podręcznik do nauki języka polskiego dla dzieci, Katowice.

Baldick Ch., 2001, Legend, w: The Concise Oxford Dictionary of Literary Terms, LondynNowy Jork.

Chotomska W., 2001, Legendy polskie, Warszawa.

Cieszyńska J., 2006, Dwujęzyczność, dwukulturowość - przekleństwo czy bogactwo?: o poszukiwaniu tożsamości Polaków w Austrii, Kraków.

Czerkies T., 2012, Tekst literacki w nauczaniu języka obcego (z elementami pedagogiki dyskursywnej), Kraków.

Czetwertyńska G., 2015, Problemy współczesnych nauczycieli polonijnych w Wielkiej Brytanii w kontekście propozycji programowych MEN, „Polski Uniwersytet na Obczyźnie w Londynie. Zeszyty Naukowe", t. 3, s. 83-94.

Czetwertyńska G., Krasuska M., Mochól S., Petri K., Poradnik dla animatorów szkolnictwa polonijnego, nauczycieli i rodziców, http://www.polska-szkola.pl/images/moodledata/1/poradniki/ poradnik_animatorzy_web.pdf [10.06.2020].

Dębski R., 2009, Dwujęzyczność angielsko-polska w Australii. Języki mniejszościowe w dobie globalizacji i informatyzacji, Kraków.

Dunin-Dudkowska A., Trębska-Kerntopf A., 1998, Teksty prymarne, adaptowane i sekundarne w nauczaniu języka polskiego jako obcego na poziomie średnim - problemy i postulaty, „Acta Universitatis Lodziensis. Kształcenie Polonistyczne Cudzoziemców”, t. 10, B. Ostromęcka-Frączak (red.), s. 35-41.

Gaze M., Góralczyk-Mowczan P., 2015, Błędy w adaptacjach tekstów literackich (na podstawie prac studentów specjalizacji Nauczanie Języka Polskiego Jako Obcego), „Acta Universitatis Lodziensis. Kształcenie Polonistyczne Cudzoziemców”, t. 22, G. Zarzycka (red.), s. $238-249$.

Gaze M., Archman M., Hrycak-Krzyżanowska D., Synowiec M. (red.), 2019, Legendy polskie na A2. Podręcznik dla dzieci polonijnych i nie tylko, Londyn.

Głowiński M., Kostkiewiczowa T., Okopień-Sławiński A., Sławiński J., 2008, Słownik terminów literackich, Wrocław.

Hajduk-Gawron W., 2019, O budowaniu zaplecza teoretycznego glottodydaktyki polonistycznej. Uwagi na marginesie „, Podstaw dydaktyki języka polskiego jako drugiego. Podejście integracyjno-inkluzyjne” Przemysława Gębala, „Postscriptum Polonistyczne, t. 1 (23), s. 291-298, http://www.postscriptum.us.edu.pl/wp-content/uploads/2019/09/Postscriptum-2019-23TEXT.pdf

http://polska-szkola.pl/db/web/database/baza-danych-szkol, [10.06.2020].

Jędryka B., 2012, Język polski w polonijnej szkole. Na przyktadzie badań przeprowadzonych w Clark-New Jersey, USA, Warszawa.

Kozłowski A., 1991, Literatura piękna w nauczaniu języków obcych, Warszawa.

Lipińska E., 2003, Język ojczysty, język obcy, język drugi: wstęp do badań dwujęzyczności, Kraków. 
Lipińska E., Seretny A., 2019, E|I|Ree|migracyjny język polski, „Języki Obce w Szkole”, t. 4, s. 5-10. Michułka D., 2008, Baśń jako tekst w nauczaniu obcokrajowców - „Waligóra i Wyrwidą” Kazimierza Władysława Wójcickiego, „Acta Universitatis Lodziensis. Kształcenie Polonistyczne Cudzoziemców", t. 16, M. Witkowska-Gutkowska, B. Grochala (red.), s. 199-205.

Rabiej A., 2009, Lubię polski! 1 (seria: podręcznik, zeszyt ćwiczeń, poradnik dla nauczyciela), Kraków.

Rabiej A., 2010, Lubię polski! 2 (seria: podręcznik, zeszyt ćwiczeń, poradnik dla nauczyciela), Kraków.

Seretny A., Lipińska E., 2012, Miedzy językiem ojczystym a obcym. Nauczanie i uczenie sie języka odziedziczonego w chicagowskiej diasporze polonijnej, Kraków.

Seretny A., Lipińska E., 2013, Nie swój lecz i nie obcy-język odziedziczony w perspektywie glottodydaktycznej, w: Młoda polska emigracja w UE jako przedmiot badań psychologicznych, socjologicznych $i$ kulturowych, http://www.euroemigranci.pl/dokumenty/pokonferencyjna/Seretny_Lipinska.pdf [10.06.2020].

Standardy wymagań odnoszących się do poszczególnych poziomów biegłości językowej w zakresie znajomości języka polskiego jako obcego, zał. 1 do rozporządzenia Ministra Nauki i Szkolnictwa Wyższego z dnia 26 lutego 2016 r. (poz. 405).

Strzelecka A., 2008, Legendy o Łodzi jako teksty pomocnicze w nauczaniu języka polskiego jako obcego, „Acta Univeritatis Lodziensis. Kształcenie Polonistyczne Cudzoziemców”, t. 16, M. Witkowska-Gutkowska, B. Grochala (red.), s. 233-239.

Szelc-Mays M., 2014, Moje litery. Piszę na A. Podręcznik dla dzieci w wieku wczesnoszkolnym, Kraków.

Tsai N., 2010, Tekst literacki a metody nauczania języków obcych, „Acta Universitatis Lodziensis. Kształcenie Polonistyczne Cudzoziemców”, t. 17, G. Zarzycka, G. Rudziński (red.), s. $395-404$.

Zarzycka G., 2004, Linguakultura - czym jest, jak ja badać i „otwierać”?, w: A. Dąbrowska (red.), Wrocławska dyskusja o języku polskim jako obcym, Wrocław, s. 435-444.

Zarzycka G., 2008, Kultura, lingwakultura, socjokultura w nauczaniu języka polskiego jako obcego, w: A. Seretny, E. Lipińska (red.), Rozwijanie i testowanie biegłości w języku polskim jako obcym, Kraków, s. 143-160.

Zarzycka G., 2019, Kulturemy polskie - punkty widzenia, techniki ich wydobywania i negocjowania. Stosowanie perspektywy etnolingwistycznej w glottodydaktyce polonistycznej, „Acta Universitatis Lodziensis. Kształcenie Polonistyczne Cudzoziemców”, t. 26, G. Zarzycka, B. Grochala, I. Dembowska-Wosik (red.), s. 425-441. http://dx.doi.org/10.18778/0860-6587.26.29

\title{
Mateusz Gaze
}

\section{PREPARING A LEGEND FOR WORKING WITH CHILDREN FROM THE POLISH DIASPORA}

Keywords: legend, children from Polish diaspora, heritage language, text adaptation

\begin{abstract}
The article presents the problem of using legends in the process of teaching children form the Polish diaspora in Polish Staurday School. Polish education for children living outside Poland is not easy. Children usually go to Saturday Schools, which build a Polish identity for several hours a week by teaching Polish and Polish culture. Saturday school teachers often do not have the proper preparation and support, and they have a very high responsibility. The article presents the benefits of using Polish legends, which constitute (as one of the few literary texts) a common cultural space for the Polish diaspora child, parents, family and friends in Poland. Author presented how to adapt the texts of Polish legends to the language level of a child and the most common mistakes made during apatation.
\end{abstract}

